\title{
Sociologists in Search of a Social Glue
}

At the beginning of this year, the editorial team of the Russian Sociological Review and the Centre for Fundamental Sociology announced the special issue with a call for papers "Friendship, Trust, and Conflict: From Conceptual History Towards Studies of Social Ontology." We wrote:

\begin{abstract}
Warfare, social conflicts, revolutions, shifts of national borders, and mass migration continue to transform the existing social order that emerged in Europe by the end of the $20^{\text {th }}$ and the beginning of the $21^{\text {st }}$ centuries. The previous special issues of the Russian Sociological Review on borders and warfare discussed these transformations of social order that is now in jeopardy, and thus may change unexpectedly. However, the notion of social order is a complex one, and has other crucial aspects. Although dissolved and disintegrated, social order is still omnipresent despite all the challenges facing it. States and global state systems are not the only fundamental phenomena that maintain social order. While solidarity was the essential feature of civil society within the borders of nation states, theories of global society have emphasized the phenomena of mobility and touristic gaze on social worlds. However, to understand recent social and political transformations, one needs to go beyond this agenda and to focus on those aspects of interpersonal relations that are still important for social order, even within the spaces of conflicts. Among other phenomena that continue to define and maintain the "grand orders" are trust, friendship, and conflict. With this special issue, we aim to draw attention to the phenomena of friendship and trust, in which honor, reputation, and glory are fundamental features rather than observation of laws, or the gratification of egoistic needs and interests. These notions and phenomena, crucial in ancient times and in feudal society, continue to be relevant topics and the central concern in the writings of scholars of the Modern Era and the $2 \mathrm{O}^{\text {th }}$ century.
\end{abstract}

There is always a kind of preconception concerning the social world which lurks beyond any Call for Papers, although one can never be sure what will be caught in effect. Our preconception was the old and famous sociological dichotomy, Gemeinschaft/Gesellschaft, coined by Ferdinand Tönnies 130 years ago. It was simple, and at the same time, very artificial. Tönnies constructed two main ideal types of the social roughly corresponding to the two main epochs in history as seen by early sociologists. One of these types, "community," was in a sense "natural," as family, the "community of blood," or rather traditional, as are the communities of neighbors or civic communities of the antic poleis, or the burgs in the Middle Ages. Tönnies supposed the other ideal type, "society" or "associ-

\footnotetext{
(C) Alexander F. Filippov, 2016

(C) Nail Farkhatdinov, 2016

(C) Centre for Fundamental Sociology, 2016
}

DOI: $10.17323 / 1728-192 \mathrm{X}-2016-4-9-12$ 
ation," to be rather modern, based on self-interest and contracts. Two great thinkers with their different visions of the social seemingly spoke in an imagined argument on behalf of each of those ideal types: Aristotle and Hobbes. Therefore, this construction, oversimplified and unsatisfactory, but deeply rooted in the history of political thought, still remains a hidden mechanism of many conceptual contradiction in social science. Friendship and trust were two important constituents of Gemeinschaft for Tönnies (although at different stages of his intellectual evolution), they still may seem contradictory to contractually and rationally organized modernity. If we look at this contradiction more closely, we see one of the most intriguing theoretical problems in sociology. Hobbes repeatedly said that the virtues of men are not the same as the virtues of citizens, and we should take these words seriously, just as Tönnies did. All the natural bonds, all the ties between individuals established without civil help and state violence, were supposed to be possible or a rather inevitable source of quarrel in society that, according to Hobbes, only preserved itself by the force and authority of the state. War of all against all as a "natural condition" should be thought of not as being before and passed away, but as being after, and still remaining under lawful sovereignty. The state did not come to establish peace instead of war. It came to substitute natural bonds between the now-isolated individuals that were rarely portrayed by Hobbes as members of their families or clans, as friends of their friends, as those who, even being subjects of their sovereigns, still remained proud of their natural power and deserved glory. Tönnies once confessed that the people of his Gesellschaft were, in fact, the "Hobbes's people." It was an extremely important statement because he was confident that any kind of Gemeinschaft cannot be eliminated from society forever. He wanted to say that we still need more traditional, premodern, natural bonds to hold our social life intact, and that no state would be able to do it without this primordial, additional force. In fact, he said something more important and more dangerous: friendship, trust, and maybe also glory) are still there, not only to support the modern forms of social life, but also to be an alternative social glue, something that is both produced and reproduced and remaining an inner threat and a source of uncertainty to modernity. It is the same with Max Weber and his conception of charisma and ideas concerning political communities based on war ethics and the prestige of power. It is the same with many important social thinkers. There is an ambivalence in the idea of modernity. It cannot but try to eliminate elder forms of sociality, and even though it still needs them, they are still there, notwithstanding changes and transformations, because they produce and reproduce modern societies but also create problems. We need to continually reflect and screen them. This was the idea of our special issue. Now you can see the results.

The paper by Nicolas Hayoz opens the section with the theoretical discussion of the political dimension of friendship. He is not interested in the phenomena that social scientists and analysts are usually looking for, namely, the influence of informal relations on political decisions (e.g., bribery). For Hayoz, the term friendship, which is often associated with the private realm, relates to the idea of trust and civic friendship considered as a key premise for contemporary democracies to be sustainable in the age of globalization and migration. Focusing mostly on political theories, Hayoz reconstructs the notion and 
then shows its importance in defining "how to live, to work together or how to communicate politically in order to influence politics, or to change things." The next paper, entitled "Topology of Communities of Trust," continues the exploration of the notion of trust. Proceeding from Hobbes's definitions of the state of nature, Mark Alfano shows the ambivalence of what he describes as "communities of trust." On the one hand, these small communities enable close relationships between members, and thus may serve as sources for various goods which are usually not easily available outside of these communities. On the other hand, their size can bring problematic features into being, e.g., an isolation from large society and relational distrust. The exploration of trust continues in the paper by Irina Trotsuk who provides an overview of how sociologists study trust from different standpoints. In details, she shows how trust is studied within qualitative and quantitative research. She advocates a narrative analysis as the methodological way to overcome the limitations of the existing approaches. The life of rural dwellers, as Trotsuk points out, can be an ideal research case for the study of trust using narrative analysis. The research paper by Elena Omelchenko does not directly engage with the topic of trust. Yet, it can be viewed as a valuable contribution to the understanding of how social order emerges within small and highly hierarchically-organized communities, i.e., ones that can be observed in prisons. Using the data from the interviews with female prisoners, she describes how the "male" (in social terms) system of recognition, power, and authority is installed within female communities. This empirical case once again shows that, beyond legal and rationalized regulations, there are also rules which shape communities and relations on a fundamental level; in the case of female prisons, these rules have an impact at the bodily level. Another empirically based paper addressed the notion of political glory by exploring the political myths of current political discourse in Russia. Maria Shteynman looks at recent public politics of history, and argues that contemporary political myths in Russia communicate the message of historical glory, and thus "the past takes precedence over the present." In her study, Shteynman deconstructs several myths and corresponding memes of contemporary culture in order to indicate their sources, those of Soviet history and the glory of this Past. Three papers that close the section present studies in the field of the history of philosophy. The paper by Bystrov, Dudnik, and Kamnev details the history of $19^{\text {th }}$ century Russian philosophical tradition that reflects on the notion of friendship. The authors argue that Russian tradition is specific since it tries to establish the relation of friendship with such notions as enmity and brotherhood. However, it was a fatal mistake of Russian thinkers to put more emphasis on brotherhood, not on friendship; they did not see that enmity, to a larger extent, is a dark side of brotherhood. The next paper of the section is dedicated to the political sociology of Bertrand de Jouvenel. In his paper, Daniel Rosenberg reflects on the distinction that de Jouvenel drew between two types of authority. Close reading of the works by Jouvenel is supported by the comparison of his notions with those of other key thinkers in the field, though primarily M. Weber. Alexandra Makurova explores the writings of Gadamer with a specific focus on what friendship is, and its key place in his draft of political philosophy. Since the paper discusses the connection of friendship with the ideas of solidarity, it may be of a particular interest to 
contemporary cultural sociologists in the sense that Gadamer's political philosophy can be viewed as fruitful theoretical source for their studies. Makurova's paper can be a starting point for this kind of research.

After we put all the papers together, we realized that we still have many gaps to fill within the broad topics of friendship, trust and, social order, which belong to the fields of political philosophy and sociology. In the forthcoming issues of the Russian Sociological Review, we will try to cover some of those aspects. Ultimately, the papers in this section may be viewed as valuable sources of new theoretical and empirical insights. We hope that the papers will provoke scholars from a range of disciplines to join the debates on the contemporary relevance of the notions of trust, glory, and authority.

Alexander F. Filippov, Nail Farkhatdinov 